Trinity University

Digital Commons @ Trinity

Philosophy Faculty Research

Philosophy Department

Fall 2011

\title{
All Play and No Work: An Ontology of Jazz
}

Andrew Kania

Trinity University, akania@trinity.edu

Follow this and additional works at: https://digitalcommons.trinity.edu/phil_faculty

Part of the Philosophy Commons

\section{Repository Citation}

Kania, A. (2011). All play and no work: An ontology of jazz. The Journal of Aesthetics and Art Criticism, 69(4), 391-403. doi:10.1111/j.1540-6245.2011.01483.x

This Article is brought to you for free and open access by the Philosophy Department at Digital Commons @ Trinity. It has been accepted for inclusion in Philosophy Faculty Research by an authorized administrator of Digital Commons@ Trinity. For more information, please contact jcostanz@trinity.edu. 


\section{ANDREW KANIA}

\section{All Play and No Work: An Ontology of Jazz}

If we consider different Western musical traditions, such as classical, rock, and jazz, we can find the same kinds of entities employed in all three traditions. For instance, there are recognizable, reinstantiable songs in all three traditions. There are also events we would happily call live performances of those songs, as well as recordings of them. Yet it is also true that these kinds of entities are treated differently in each of these traditions. For instance, those who produce and listen to rock recordings take, for the most part, a very different attitude toward what counts as acceptable use of recording technology (for example, note correction) than those who produce and listen to classical recordings. Are classical and rock recordings thereby different kinds of things? There is no absolute answer to this question. In some contexts, it is unproblematic to refer to recordings in general, ignoring the differences between these two types. In other contexts, however, it may be confusing or even misleading to ignore such differences. ${ }^{1}$ One such context might be where we are trying to understand with some precision the experiences of those who listen with understanding to, say, jazz recordings. If it turns out that we cannot satisfactorily describe the experiences of a knowledgeable jazz listener without making reference to the particular ways in which jazz recordings are made (and known to be made), then that will be a reason to favor a theory that includes such distinctions.

Making such distinctions is part of what ontologists of music do. What I have elsewhere called "higher-level" musical ontology is an attempt to map the nature of and the relations that hold between various musical entities, such as works, performances, and recordings, in different musical traditions. I call such projects "higher level" to distinguish them from "fundamental" musical ontology-the more traditional search for the correct basic ontological category for musical works (Platonic universal, mereological fusion, action type, and so on). ${ }^{2}$ One kind of project in higherlevel musical ontology is the search for "the work of art" in a given tradition. As with the term 'recording,' we use the term 'work of art' in different ways. Sometimes we use it quite generally to refer to any artistic entity. Another common usage is the evaluative one, whereby we praise something for being excellent of its kind, even though it may not be art at all (for example, a paella) nor a work of art in some more restricted sense (for example, a single brushstroke). In higher-level musical ontology, however, the relevant sense of 'work of art' is its use in referring to something like the primary focus of appreciation in a given tradition. ${ }^{3}$ (This gloss will be refined below.) So, for instance, we might say that the work of art in the tradition of painting is the painting. By itself this may not sound particularly edifying, but it is useful to keep in mind if we want to understand the role of studies for paintings in the painting tradition. It might be difficult to argue that many such studies are not art, yet any theory of painting that could not account for the difference between studies and fully fledged paintings would be incomplete.

My goal here is to identify the work of art in jazz, if such there be, in the higher-level sense just adumbrated. A survey of the literature on the ontology of music, together with a little knowledge of jazz, suggests four possibilities for a jazz ontology. I consider these suggestions in turn. ${ }^{4}$ As will become apparent, the measure of any such theory is coherence with jazz discourse and practice, that is, what people knowledgeable about jazz say 
and, even more importantly, do. The underlying assumption of this methodology is that art forms, such as jazz, are social practices that depend on understandings that, though shared by most participants in the practice, may not be directly or immediately consciously accessible. Thus, everyone stands to gain from a successful project of this kind-not only those unfamiliar with jazz, but also those deeply involved in it. The former will gain an understanding of an artistic tradition unfamiliar to them; the latter may come to understand something new about experiences that are deeply important to them. ${ }^{5}$ It is also worth noting, however, that this is a comparative project in musical ontology. That is, I am interested in how jazz is similar to, and different from, other Western musical practices. As a result, I strive to use terms, notably the term 'work of art,' univocally across the different traditions I discuss. I return to this point below.

I take as my primary target "standard form" jazz, where a paradigmatic performance consists of a number of solo choruses framed by a pair of statements of the head. But what I say should apply to almost all jazz, including free improvisation and performances of highly detailed jazz scores. There are two major jazz traditions that my view may not apply to, however. One is the jazz song tradition, by which I mean the tradition in which the focus of the performance is a singer singing a song. The fact that it is a relatively autonomous tradition can be seen in its being given a separate treatment (some might say its being largely ignored) in historical, musicological, and philosophical writing about jazz. ${ }^{6}$ (I do not mean to exclude vocalizations within the instrumental tradition, such as scatting solos by instrumentalists, Dizzy Gillespie's calls of "salt peanuts!", and even the applause, laughter, and other commentary of the performers that make up part of some instrumental jazz performances.) The other tradition that may not fit the ontological view I defend is jazz "fusion." These exceptions are not arbitrary, though they can only be made sense of once I have presented my arguments. Their justification is of the same sort I have offered for projects in higher-level musical ontology in general. It seems to me that people listen to jazz singing and fusion in importantly different ways from those in which they listen to "standard form" instrumental jazz, because musicians in these traditions are doing significantly different kinds of things; part of this difference can be captured by a higher-level ontological theory, just as those who offer ontologies of classical music, for instance, commonly restrict the historical scope of their theories and exclude classical electronic music from consideration. I briefly note my views about these exceptions below.

\section{JAZZ AS A TRADITION OF WORKS FOR PERFORMANCE}

The first suggestion I consider is that jazz is ontologically like classical music. ${ }^{7}$ Just as The Rite of Spring is a work of classical music, composed by Igor Stravinsky and performed by numerous groups (led, in a few cases, by the composer himself), so "Sophisticated Lady" is a work of jazz music, composed by Duke Ellington and performed by numerous groups (led, in a few cases, by Ellington). This view is defended explicitly by Carol S. Gould and Kenneth Keaton, and by James O. Young and Carl Matheson, but it seems to be implicit in many other discussions of jazz, whether philosophical, musicological, or popular. ${ }^{8}$

i. Locating the Work. One challenge for the ontologist who argues that jazz is like classical music is to argue for a principled way to determine which sound structure out of a range of potential candidates is the work. ${ }^{9}$ For example, in order to accurately perform the work implicit in a particular performance of "Body and Soul," should one attempt to produce (i) sounds with exactly the sonic profile of this performance, (ii) sounds indistinguishable to a knowledgeable listener from those of this performance, (iii) sounds recognizable as an imitation of this particular performance, (iv) a performance with the same harmonic or melodic structure, or what? ${ }^{10}$ A common suggestion is that the work in jazz is quite a coarse structure, something like the harmonic structure plus a melody, or at least a melodic shape. Young and Matheson call this the "canonical model."11 But they point out problems with both parts of the proposal. For a start, in some performances of a standard, no melody close to the original is played. (Lennie Tristano's performance of "All of Me" is their example.) But if we discard that aspect of the proposal for what the work is, and rely on the harmonic structure alone, we are left with too coarse a structure, since there are many different standards with the same harmonic structure. The classic 
example here is the "Rhythm changes"-the harmonic structure of Gershwin's "I Got Rhythm"-that is shared by many different standards, such as Charlie Parker and Dizzy Gillespie's "Anthropology" and Lester Young's "Lester Leaps In."

Young and Matheson also consider performances of free jazz. ${ }^{12}$ Relying on harmonic structure or melody to determine the work here, they argue, would result either in free jazz performances' not being of works, or in their being of works that are instantiated in only one performance. ${ }^{13} \mathrm{I}$ am not sure that the latter suggestion is even coherent. The concept of a musical work that Young and Matheson are working with is that of a work for performance of the kind common in classical music. But these are works appropriately, intentionally, and commonly performed multiple times. This is a fundamental part of the culture of classical music. But this is clearly not what is going on in free jazz. It is not just a coincidence that free jazz "works," conceived as melodic and/or harmonic structures, do not receive multiple performances. Nor is the problem that it would be too difficult to perform such a "work" again. Merely making the attempt would be considered bizarre, and is arguably antithetical to the whole ethos of free jazz.

Young and Matheson consider two other candidates for the work in free jazz, both of which are also considered by Richard Cochrane. ${ }^{14}$ Cochrane defends a conception of musical works as sets of rules concerning what is compulsory, forbidden, and optional in the production of a performance. He then points out that there are such rules governing free jazz performances. For instance, you must not regurgitate Coleman Hawkins's "Body and Soul" over and over again throughout a free jazz session. One conclusion Cochrane draws is that many, or all, free jazz performances may be considered performances of one and the same work. This strikes me as a reductio of the theory. Young and Matheson similarly say that this suggestion "does not bear serious consideration." 15 If these sorts of rules constitute musical works, then all classical performances can be considered performances of the same work, as can all performances with the same harmonic structure, and so on. There is more to a work than merely being a common denominator of several performances.

But the other suggestion considered both by Cochrane and by Young and Matheson is amenable to the latter's general conclusion. Young and Matheson suggest that the work in free jazz performances might be something like a cluster of motives-with neither melodies nor harmonies determined. ${ }^{16}$ On this view, two takes for Ornette Coleman's Free Jazz might be considered two performances of the same work. This accords well with Young and Matheson's general conclusion that there is no single kind of work in jazz. We cannot pick just one level of description, one kind of structure, to designate as the right level at which to look for jazz works: "Jazz works are defined ... by sets of tacit guidelines for performance. Two performances... can follow these guidelines and be said to instantiate the same jazz standard. No completely general account can be given of these guidelines, which differ from one period and style of jazz to another."17

This conclusion might sound initially like one Stephen Davies has argued for with respect to classical music. ${ }^{18}$ Davies argues that there is variation in the ontologies of classical works. Some are "thinner" than others; that is, fewer of the properties of a fully authentic performance are determined by the work. So, like Young and Matheson, Davies argues that there is no single ontological level at which we should look for works in classical music. The musico-historical context, in conjunction with what the composer does, determines the constitutive features of the work.

But this seeming agreement between the ontologies of classical and jazz-between Davies on the one hand and Young and Matheson on the other-conceals an important distinction. Although Davies argues that classical works are socially constructed, in that their musico-historical context partly determines their constitutive features, he resists the further claim, argued for by some, that the constitutive features of works change over time. ${ }^{19}$ For instance, Mozart's piano concertos include "gaps" where the performer is supposed to improvise a cadenza. But, like many composers, Mozart wrote out cadenzas for several of his concertos, as options for those who were unable to improvise. By the end of the nineteenth century, such "gaps" were no longer left in concertos, for various reasons:

Some have explained this shift by citing the impatience of composers toward performers who would disfigure their compositions by inappropriate improvisations. Moreover, as we see it, one must consider the influence 
of the romantic concept of the artist as an authoritative and solitary hero. Then, too, as musical composition expanded during the romantic period, the integrity of the musical structure became too complex for a spontaneous improvisation of pitches and durations to be dependably supportive. ${ }^{20}$

But this did not mean that the cadenzas Mozart wrote out for his concertos became constitutive of those works. Perhaps as improvisation became a lost art to most classical performers Mozart's cadenzas were played more frequently, but the work still calls merely for some cadenza, preferably improvised, in the style of Mozart's day.

The variations in jazz performances that Young and Matheson point to are thus not like the variations in classical works that Davies discusses. Recall that Young and Matheson claim that (1) "two performances...can follow [the same] guidelines and be said to instantiate the same jazz standard," and that (2) "no completely general account can be given of these guidelines, which differ from one period and style of jazz to another." ${ }^{21}$ If the structural level at which the jazz work is located differs from work to work and from one period to another, as it does in classical music, then the period in which a particular standard is composed determines the ontology of that work. Take Ellington, for example-as good an example as there is of a composer of jazz works. If Ellington composed "Sophisticated Lady" with a particular ensemble in mind (characterized in terms of number and kind of instruments, say), and his musico-historical context allows such things to be work-determinative, then on the current proposal, any authentic performance of that work will require that same ensemble, just as any authentic performance of Bach's Fifth Brandenburg Concerto requires a harpsichord. But the jazz case clearly does not parallel the classical here. Chick Corea's performance of "Sophisticated Lady" is just as authentic as anyone else's-for instance, Ellington's-despite its utilizing very different forces, containing no obvious statement of the melody, and substituting chords all over the place. One response to this example is to claim that I have beefed up Ellington's work, claimed it is thicker than it in fact is. This response inherits all the problems of the theory that jazz works are ontologically very thin. But the more serious problem for the ontological variety Young and Matheson propose is that the variation in performance guidelines "from one period and style of jazz to another" is not variation that would affect how to extract a piece from a performance or score, say, as the relevant variation does in classical music. Thus, it is not variation in the ontology of various works. Rather, the variation in jazz is variation in the performance guidelines about how to approach any given piece. Corea approaches "Sophisticated Lady" in a very different way from Ellington, which is different again from Charlie Parker's approach. If this is variation in ontology, then Young and Matheson are saying that Corea's "Sophisticated Lady" is a different work from Ellington's. And this is clearly not their intention. Thus, their proposal of a variable ontology of jazz does not solve the problem of the location of the work.

I have expressed skepticism about two views of how we should characterize jazz works if the ontology of jazz is like that of classical music: the view that all works in the tradition are thin and the view that there is an ontological variety of works in the tradition. This alone suggests it would be worthwhile investigating alternative ontological models. But it might also seem to leave me with a significant datum about jazz practice unexplained, namely, the fact that jazz performers and audiences routinely identify jazz performances as versions (let us say, not to beg any questions) of "Sophisticated Lady," "Don't Get Around Much Anymore," and so on. Does the fact that there is convergence on these judgments not suggest that there is some thread running through all versions of "Sophisticated Lady" that the performers are clinging to and audiences detecting? Something like this is doubtless going on a lot of the time. But it is important to realize that this feature of jazz practice could be accounted for under various ontological models. For instance, I have argued elsewhere that a rock "cover" does not stand to the song it shares with its "original" in the same relation that a classical performance stands to the work it is of. ${ }^{22}$ Similarly, the fact that two jazz performances entitled "Sophisticated Lady" have something in common does not immediately imply that the thing in question is a work of which these are performances (in the sense of these terms operative in classical practice). Further, though more controversially, I would argue that these sorts of connections are of relatively little interest to jazz musicians and audiences, compared with the interest of a classical audience in what work is being 
performed. I return to this point at the end of the article.

\section{ii. Improvisation. A different objection that} might be raised against the idea that jazz is a tradition wherein enduring pieces are given repeated performances is that jazz is essentially an improvisatory tradition. ${ }^{23}$ If improvisation is central to a jazz performance, then surely the performance cannot be of a preexisting work?

Consideration of classical music shows that the inclusion of improvisation in a performance is not a guarantee that there is no enduring work being instantiated. Consider our Mozart piano concerto again. The fact that such a work contains one or more "gaps" wherein the soloist is supposed to improvise a cadenza, displaying both her understanding of the work and her technical prowess, does not militate against Mozart's concertos' being works of art in the relevant sense. Or, going further back, consider baroque ensemble compositions. They frequently contain continuo parts wherein only the melody, bass line, and harmonies are determined. The individual notes of the inner voices which realize those harmonies are at the discretion of the performer, and a performer well versed in this tradition is able to improvise such counterpoint on the spot. In these works, as in jazz performance, improvisation is required of the performer. They are works nonetheless.

On the other hand, it is uncommon to find works in the classical tradition that are as thoroughly or centrally improvisatory as jazz works must be if they are like classical works ontologically. There will be examples, of course, from the late twentieth-century avant-garde, but these are protests against the tradition rather than paradigms, whereas highly improvisatory jazz works are paradigmatic. Moreover, in classical performances where there is an amount of improvisation similar to that in a jazz performance, we are not so ready to call the performance one of a preexisting work. Stephen Davies gives the example of Bach's improvisation of a three-voice ricercar on a theme provided by King Frederick II of Prussia. It would be wrong to call Bach's performance a performance of Frederick's work. What Frederick provided was something like a springboard for Bach's creativity. ${ }^{24}$ Thus, if we are to follow through with the parallel to classical music, we must similarly conclude that jazz improvisations are not performances of preexisting works.
Despite (or because of) its centrality in the philosophical literature on jazz, there has been much confusion over the concept of improvisation and its relations to performances, works, and scores. While there is no space here to engage with all the literature on the nature of improvisation, I offer a gloss of the term that I hope many will find intuitive, and compare it with a few recent alternative suggestions. ${ }^{25} \mathrm{I}$ take the concept to be quite general, but to put it in musical terms, an improvisation is a performance event guided by decisions about that event made by the performer shortly before the event takes place. 'Shortly before' should be construed so as to make the inclusion of "spontaneity" in the proposed definition redundant. ${ }^{26}$ This account allows for free improvisation and for improvisation in the performance of a piece. It also entails that one cannot necessarily tell just from listening to a performance whether it is improvised, or which aspects of it are; there is an intentional aspect to improvisation. If a classical performer has practiced his interpretation of a piece over and over again, but during the performance "loses it" for a moment and plays a cluster chord where he did not intend one (even at that moment, causing him to curse under his breath), that is not improvisation. On the other hand, a classical performer may improvise her interpretation anew during each performance. ${ }^{27}$ The proposal differs from previous accounts such as those of Philip Alperson and of Gould and Keaton in not requiring that the decisions be about a work. ${ }^{28} \mathrm{It}$ also differs from Gould and Keaton's proposal in requiring spontaneity. I take both of these to be prima facie advantages of my account over these others.

My account also differs from Young and Matheson's in one important respect. Young and Matheson argue that "an improvised performance is one in which the structural properties of a performance are not completely determined by decisions made prior to the time of performance," where "structural properties" include "melody, harmony, and length" as opposed to "expressive properties" like "tempo, the use of vibrato, dynamic, and so on." ${ }^{29}$ I reject this restriction of the domain of improvisatory decisions. I see no reason to deny that a performer could improvise, say, the rubato in her performance. Nor do Young and Matheson provide an argument for this conclusion. They claim that "the line between expressive and structural properties... must be drawn if we 
are to avoid the conclusion that virtually every musical performance involves improvisation." ${ }^{30}$ But when it comes to the example that is supposed to "clarify this point," we hear that a "concert pianist who performs a Beethoven sonata does not improvise.... Even if the player spontaneously adds rubato or varies the tempo, she or he is not improvising... since she or he is simply varying the expressive properties of the work." ${ }^{31}$ This is a circular argument if ever there was one. A further question the proposal raises is what the status of the expressive properties of a (structural) improvisation is. Since the notes of the improvisation have not been worked out in advance, neither, presumably, have the expressive properties. But according to Young and Matheson, such properties cannot be improvised. Perhaps their view is that the improvisation of structural features opens the way for the improvisation of the expressive features. But this seems an arbitrary restriction on the possibility of improvising expressive features.

Young and Matheson are right to emphasize that a performance can be improvisatory without being completely improvised from scratch. ${ }^{32}$ One can practice improvising, work up a repertoire of licks, figure out various ways around tricky progressions, and so on. As we have already seen, even "free" jazz improvisations are not without their implicit conventions. But I see broader scope for "improvisation" than Young and Matheson do. At the minimal end of the improvisation spectrum, I would place a performance of a classical work where the performer decides to improvise the vibrato, or rubato, or tone color of a short part of the piece. There will be no way for the audience to know that the performer is so improvising, nor would the improvisation be noteworthy, even if well executed. And such improvisation would be well within the bounds of a completely authentic performance of, say, a Romantic violin sonata. In a jazz solo, of course, we expect a performer not to have memorized exactly which notes she will play during a given performance. But across the board we can roughly say that the more decisions get made during the performance, the more improvisatory it is. ${ }^{33}$

It is worth noting that I have ignored the question of what determines whether a given performance is an improvisation, preferring instead to discuss whether a given performance event is improvisatory. Although, in our discourse about music at least, we tend to talk more about "improvisations" than "improvisatory" events or features, I believe that there is no clear line between "an improvisation" and a performance with many improvisatory elements. This suggests that there may simply be no answer to the question of what makes a performance an improvisation. ${ }^{34}$

To return to the point of this exploration of the nature of improvisation and its role in jazz: while we have seen that "improvisation" is univocal across the classical and jazz traditions, this does not by itself answer any ontological questions about jazz, even given an ontology of classical music. Neither what is notated in the jazz tradition nor the mere fact that there is improvisation in a jazz performance proves that there are not enduring works in the jazz tradition that are instanced in performances. However, the sheer amount of improvisation in a typical jazz performance and the centrality of improvisation to the tradition seem to indicate that the proposed candidate for the enduring work in jazz, the standard, is more an aid to the performers' real-time creativity, like Frederick's theme for Bach's ricercar, than a work to be instanced in multiple performances, like Beethoven's Fifth Symphony. ${ }^{35}$

iii. The Centrality of Performances. As a final line of defense, the ontologist who believes that jazz and classical music share an ontology might point to the most convincing cases for that commonality: apparent works for performance that receive multiple performances and have very little room for improvisation. Duke Ellington provides some good examples of this as a central figure in the evolution of jazz widely considered to be one of America's great composers. Ellington's "Concerto for Cootie" seems to be a work like a classical concerto: fully scored for a particular kind of ensemble and, while making use of a particular performer's skills, leaving no more room for improvisation than a typical late Romantic work for performance. One might similarly argue that many of Ellington's arrangements for his band over his lifetime are ontologically like classical works and transcriptions. Many are completely scored, with little room for improvisation.

I argue, though, that in the case of Ellington's various arrangements of a given piece, such as "Rockin' in Rhythm," and in jazz more generally, what we have is not one work, several transcriptions of that work, and multiple performances 
of each transcription, but more simply a host of performances to be compared with one another, on their own terms as it were, rather than as performances of some other entity-a work. ${ }^{36}$ Why? First, the incessant rearranging that Ellington did of almost all his pieces suggests that he was constantly thinking of new ways to produce exciting performances, rather than perfecting an enduring entity. Of course, classical composers revise their works, but even in the most extreme cases, there are nowhere near the number of reworkings common in jazz, even with such a "composerly" musician as Ellington. Another sign that Ellington is focused on the performance rather than some reinstantiable work is that his arrangements were made for particular personnel as his ensemble changed, focusing on their particular abilities. Again, classical composers write with particular performers in mind, but they cannot restrict the performance of their works to particular performers. ${ }^{37}$ As André Hodeir writes, "the 'classical' composer can still afford not to know who is going to play his music; this attitude is out of the question for the true jazz composer. It would be unthinkable for an arranger to have a piece played by Duke Ellington's band when it was originally written for Count Basie's." 38

Second, the very few instances where Ellington (or anyone else) did not rearrange a piece but continued to perform it, as with "Concerto for Cootie," are not enough to determine the ontology of the entire tradition. Compare the practice of "remakes" in film. A small number of remakes are very close to their originals-Gus Van Sant's Psycho (1998), for instance. This does not make cinema an art form of interpreted instances of works-the shot structure that Van Sant's movie shares with Hitchcock's, for instance. Nor does it make it the case that in this one particular case we have such an isolated ontology. Van Sant's work is a work of cinema and thus shares its ontology with the other works in that tradition. ${ }^{39}$ Performances of "Concerto for Cootie" are jazz performances and thus not performances of works despite their superficial similarity with the ontology of classical music (contra Hodeir). ${ }^{40}$ A succinct way of putting these points is that no sound structure that any jazz performances share is a primary focus of critical attention in the jazz tradition.

The above reflections on the problem of locating the jazz work, if any, the nature and role of improvisation in jazz, and the relations between various jazz performances with the same name strongly suggest that jazz is not ontologically like classical music: it is not a tradition of performances of works.

\section{JAZZ PERFORMANCES AS WORKS}

An obvious way to develop the ideas sketched above would be to suggest that though jazz performances are not works in the classical sense of being for repeated performance, they are nonetheless products of intentional human action intended for aesthetic appreciation (or whatever you think makes something art) and thus are artworks just as much as sculptures or symphonies are. That is, the event itself, rather than the sound structure it instantiates, is a work of art. This view is defended by Philip Alperson and arguably by Garry Hagberg and Stephen Davies. ${ }^{41}$ Though Alperson talks of the improviser as the spontaneous composer of a sound structure, he also argues that improvisations should not be heard as interpretations of works and that "if anything, musical improvisation seems ontologically closer to the creation of a wood sculpture ... than to a conventional [that is, classical] musical performance." ${ }^{42}$ Hagberg explicitly argues for the "work-indeterminacy" of jazz as a result of the considerations discussed in the previous section. But I think that without his implicit assumption that works of art in jazz must be repeatable sound structures, he might be tempted by the view that jazz performances themselves are works of art.

I have no objection to the basic idea behind this suggestion, that individual performances in their own right (as opposed to those performances considered as performances of independent works) are the primary focus of critical attention in jazz. However, I believe that there are compelling reasons to reject the characterization of this view as the view that jazz performances are works of art, strictly speaking. Recall that this is a project in comparative musical ontology. Thus, we ought to use our terms consistently if at all possible. And one central term in any art-ontological discussion is 'work.' What do we mean when we say that a particular type of entity is "the work of art" in some tradition? I suggested above that at the very least we seem to mean that it is a primary focus of appreciation in the tradition. But we must mean more than that. Performances of classical works are a 
primary focus of appreciation, yet we do not call them works of art in their own right (except occasionally in an honorific sense). What distinguishes classical musical works from performances, I suggest, is that works are enduring entities or, more prosaically, objects. This, then, is at least one further condition we require for being a work of art. ${ }^{43}$ Again, this is a claim in higher-level ontology. I am not taking a stand here on the distinction between objects and events, as someone debating metaphysical four-dimensionalism might. Rather, I am suggesting that the distinction we ordinarily make between objects and events marks one boundary between what might be a work of art and what could not be.

Having said this, I should note that it is not the words we use but the concepts they stand for that I am most interested in here. I mentioned at the outset three different ways in which we commonly use the term 'work of art.' We could certainly use the term to refer to things that are simply a primary focus of appreciation in the arts, regardless of whether they are objects or events. But if we did so, we would need another term to mark the subset of these things that we treat differentlythose that are enduring entities. Given the way we use these terms pretheoretically, however, I see no reason to adopt this new usage.

If all this is correct, then jazz performances cannot be works of art, at least in the sense in which Beethoven's Fifth Symphony is a work of art. Jazz performances are surely a primary focus of appreciation in the jazz tradition, but they are not enduring entities. If Alperson and Hagberg were to agree with my general conclusions about works of art, their views could easily be modified into the ontology of jazz I ultimately defend here. We disagree not about the nature of jazz, I believe, but about the nature of artworks. Thus, I will focus here not on their arguments, but on the roles that the concepts of work and performance play in creative and appreciative musical practice, in an attempt to bolster the idea that musical works must be enduring entities.

First, recall that if jazz performances are works of art in their own right, then so must classical performances be, since classical performances are produced with an eye to their being aesthetically rewarding (or whatever your criterion of arthood requires) and are a primary focus of appreciation in the classical tradition. Yet, in classical music, performances are precisely distinguished from the works they are of. Of course, an advocate of this proposal might recommend this change to classical discourse, pointing to the ill-founded but long-running valorization of the work over performance in musicology and aesthetics. But we can do away with this baseless valorization without having to change our concept of a work of art. The sense of 'work of art' that we are concerned with is not an evaluative one, thus it would not be a slur on jazz to claim that there were no jazz works in this sense.

A more important consideration, however, has to do with the durability of works of art, compared with the fleeting nature of jazz performances. This is where Alperson's comparison of jazz performances with wood sculptures breaks down. Works of art are not just things intended to be worthy of aesthetic appreciation, but things worked on over time so that their aesthetic or artistic value can be maximized. ${ }^{44}$ Jazz performance, to the extent that it is improvisatory, is not perfected ahead of time, like these paradigms of work creation. And note that this is precisely one of the grounds upon which jazz music has been misevaluated throughout its history. Critics familiar with other musical traditions have accused jazz of being harmonically uninventive and of containing lots of wrong notes, in both senses of "inappropriate for this musical moment" and "poorly executed." Discussing Miles Davis, for example, Robert Walser writes:

"The problem of Miles Davis" is the problem Davis presents to critics and historians: how are we to account for such glaring defects in the performances of someone who is indisputably one of the most important musicians in the history of jazz?... The uneasiness many critics display toward Davis's "mistakes," and their failure to explain the power of his playing, suggest that there are important gaps in the paradigms of musical analysis and interpretation that dominate jazz studies. ${ }^{45}$

Admittedly, some of these criticisms have been the result of critics' ignorance of jazz's harmonic traditions (for instance, the neutral third it inherited from some West African music) and its widened conception of timbral possibilities (stretching back through Ellington's horns' jungle effect, to precursors such as Robert Johnson's blues guitar and Leadbelly's field-holler vocal inflections). But much of it has come, I think, from a misconception of jazz performances as like, or intended to be like, classical works-worked out in 
advance to maximize their aesthetic value. Those knowledgeable about jazz, on the other hand, have found value precisely in the in-the-moment extemporizing that jazz performance makes possible. Note also that if this "perfectibility" is a mark of work-hood, then classical performances are more like works of art than jazz performances since in the classical tradition one is expected to learn the piece and work out one's interpretation thoroughly before performing it. Though one does something akin to this in preparing for jazz performances-developing improvisatory techniques, learning various changes, building a repertoire of licks-one cannot work out one's improvisation ahead of time; it would no longer be an improvisation, for the reasons discussed above. Thus, if one is content with the traditional division of classical music into works and (nonwork) performances of them, one can only hold that jazz performances are works of art on pain of inconsistency.

\section{JAZZ RECORDINGS AS WORKS}

It has been argued that the work of art in rock music is the recording, that these are the enduring entities that are the primary focus of appreciation in the rock tradition. ${ }^{46}$ This theory might be coopted by the jazz ontologist as a third proposal. For recordings provide a way to turn a fleeting performance event into an enduring object. As far as I know, no one has proposed this as a theory of jazz ontology. However, Lee B. Brown conjectures that "as recorded, [jazz] may have an entirely different phenomenology from that of the living thing. Indeed, it may have a different ontology." ${ }^{47}$ He also claims that André Hodeir's talk of jazz "works" clearly refers to recordings. ${ }^{48}$

Theodore Gracyk, in his arguments for recordings' being the works of art of rock music, points to the centrality of records in the tradition: records, rather than live performances, are what people mainly talk about in rock, and people learn how to play by listening to and imitating their favorite records. ${ }^{49}$ Similar claims could be made about jazz. Musicians exchange and talk about recordings; they learn to play by imitating their favorite recordings; and the recording studio has had other wide-reaching effects on the history of jazz. For instance, Louis Armstrong and his Hot Five played only in the recording studio, in part because local Chicago audiences did not want to hear their hot
New Orleans style. Without recording technology, then, it is not clear they could have had so great an influence on jazz.

However, as I have written elsewhere:

For all the similarities, there are important differences between rock and jazz approaches to recording; here jazz seems to be a lot closer to classical music than it is to rock. Just as notation enabled classical composers to create more and more complex enduring musical works, recordings enable the preservation of works with all the replete detail of a sound event. Rock, like classical electronic composition, embraced this aspect of recording technology to the extent that informed rock audiences do not expect rock recordings to be transparent to live performance events. Both classical and jazz audiences, on the other hand, expect the phenomenal performance heard on a recording to be connected to the active performance of the musicians in the right way. Different takes may be spliced together, and extraneous noise removed, but nothing should be done to cause the recording to represent a sound event that the musicians would be incapable of producing live. As live performance traditions, both classical and jazz music have embraced recording technology's ability to represent artists' capabilities in the best light, but both traditions maintain a distinction between authentic recording practice and studio trickery. In both traditions, one is supposed to listen through the recording to the represented performance, rather than to the recording as a studio construction..$^{50}$

It is also worth noting an argument parallel to one given in the previous section: if one argues that jazz recordings are works of art in their own right, classical recordings must be too, by parity of reasoning. But, again, though some might embrace this conclusion, note that (i) recordings must be works in a different sense from that ordinarily applied, since a recording of Elgar's Sea Pictures in some sense manifests the "ordinary" workthe orchestral songs, and (ii) as in the case of live performances, classical recordings probably have more claim to being works of art than jazz recordings, since the interpretations they contain can be worked on over time with a clear conscience, unlike jazz improvisations. These consequences are to be avoided if possible. Another way of grasping this point is to think about the asymmetric dependence of recorded jazz practices on live jazz practices, just as is the case with classical music, in stark contrast to rock, as I have argued elsewhere. ${ }^{51}$ 
Jazz and classical music are alike, then, in being live performance traditions. But they are unalike in that classical performances are performances of works, while jazz performances are not. I have also argued that jazz performances, like all performances, cannot be works of art. What views remain for the jazz ontologist to subscribe to?

\section{JAZZ AS AN ART WITHOUT WORKS}

A final possibility, the one I favor, is that in jazz there are no artworks. This view is implicit in an article by Brown. ${ }^{52}$ It is more explicit in his own later summary of that article's conclusions: "A genuinely improvisational performance, even though based upon ... a mini-work [such as a Broadway tune], is not itself a musical work, with everything that this concept implies. In particular... such a performance is not re-identifiable in multiple instances." 53

Stephen Davies argues that jazz performances are not performances of works, but he does not go so far as to say that there are no works in jazz. Rather, he implies that in jazz the performance is the artwork, as noted above. ${ }^{54}$

My view may sound unappealing and unnecessary. It sounds unappealing if you think of the production of artworks as the central goal of any artistic tradition. ${ }^{55}$ But there is no reason why this should be so. I have already mentioned my agreement with much recent musicology that performances should not be given second place to works in discussions of classical music. So why should an art with only performances and no works be considered inferior to one with only works (such as sculpture) or one with both works and performances (such as classical music)?

My view may sound unnecessary since one could accept all that I have said above and yet find enduring musical objects in the jazz tradition. But this is to ignore the distinction between artworks and other kinds of art objects. Ellington wrote parts for his musicians to play, and he expected them to stick to what he wrote, just as a classical composer expects her performers to play what she wrote. Ellington thereby brought a multiply instantiable sound structure into existence. But where Ellington crucially differs from the classical composer is that he did not expect nor even desire future performers-himself and his band included-to play what he wrote on this occasion.
This is bound up with the fact that future performances that are "of the same piece" do not get assessed as instances of some third entity-the work. Just as rock covers are compared directly with one another, not (primarily) as performances of the same song, so jazz performances based on the same head get compared directly with one another, not (primarily) as performances of the same work. Standards such as Ellington's are worthy of attention, but in jazz such compositions are more vehicles for performances than vice versa. This can be seen in a whole range of jazz practices, from the complete normalcy of picking and choosing whatever aspects of the standard suit the contingencies of the performance and preferences of the performers to the jokey arbitrariness with which many improvisations, though destined to become standards, are named.

In summary: jazz, like classical music and unlike rock, is a live-performance tradition. However, the centrality of improvisation to jazz and the direct comparison of performances with one another, rather than as instances of some separate enduring entity, show that, unlike classical music, jazz is not a work-performance tradition. Since performances are different kinds of things from works of art, yet are the primary focus of critical attention in jazz, I conclude that jazz is a tradition without works. This should not be misunderstood as an evaluative claim. The benefit of thinking of jazz in this way is a clearer understanding of what is distinctive about what jazz musicians and audiences do, compared with musicians and audiences in other musical traditions. ${ }^{56}$

\section{ANDREW KANIA}

Department of Philosophy

Trinity University

San Antonio, Texas 78212

INTERNET: akania@trinity.edu

1. For an introduction to the philosophical literature on musical recordings, see Andrew Kania, "Musical Recordings," Philosophy Compass 4 (2009): 22-38.

2. Andrew Kania, "New Waves in Musical Ontology," in New Waves in Aesthetics, ed. Kathleen Stock and Katherine Thomson-Jones (New York: Palgrave Macmillan, 2008), pp. 20-40, at pp. 32-35.

3. Others who have appealed to this kind of concept include Theodore Gracyk, in his Rhythm and Noise: An Aesthetics of Rock (Duke University Press, 1996), and David Davies, in Art as Performance (Oxford: Blackwell, 2004). 
4. For ease of exposition, I sometimes use the language of a position I ultimately reject, for instance, talking about a performance of a jazz work. But by the end of the article, the reader should see how I intend to rephrase such formulations in the language of my final proposal.

5. There is much more to be said here about the methodology of art ontology, but no room to say it. For a start, see Davies, Art as Performance, pp. 16-24, and David Davies, "The Primacy of Practice in the Ontology of Art," The Journal of Aesthetics and Art Criticism 67 (2009): 159-171; Robert Stecker, "Methodological Questions about the Ontology of Music," The Journal of Aesthetics and Art Criticism 67 (2009): 375-386; and Andrew Kania, "The Methodology of Musical Ontology: Descriptivism and Its Implications," The British Journal of Aesthetics 48 (2008): 426-444.

6. Usually a few early singers are mentioned-Bessie Smith, Billie Holiday, and Louis Armstrong-to illustrate the conflation of vocal and instrumental sounds that began in the early days of jazz. But the vocal tradition usually drops out of the picture around the Swing era. See, for example, André Hodeir, Jazz: Its Evolution and Essence, trans. David Noakes (New York: Da Capo, 1956); Donald D. Megill and Richard S. Demory, Introduction to Jazz History, 2nd ed. (Englewood Cliffs, NJ: Prentice Hall, 1989); and Frank Tirro, Jazz: A History, 2nd ed. (New York: Norton, 1993).

7. Though I argue against this view for instrumental jazz, this may be the most appropriate ontological model for the jazz song tradition.

8. Carol S. Gould and Kenneth Keaton, "The Essential Role of Improvisation in Musical Performance," The Journal of Aesthetics and Art Criticism 58 (2000): 143-148; James O. Young and Carl Matheson, "The Metaphysics of Jazz," The Journal of Aesthetics and Art Criticism 58 (2000): 125-134. For representative philosophical, musicological, and popular examples, see Philip Alperson, "On Musical Improvisation," The Journal of Aesthetics and Art Criticism 43 (1984): 17-29 (on one reading); Tirro, Jazz: A History; and Wynton Marsalis in Ken Burns's documentary, Jazz (2001).

9. Though on this proposal a work may be more than a sound structure, for simplicity I ignore this in what follows.

10. Some have appealed to the use, or lack of, scores in answering this question (for example, Young and Matheson, "The Metaphysics of Jazz," p. 125), but this is a red herring. There can be enduring works in the absence of scores, as complex oral musical traditions attest, and there can be notations that look just like scores, yet are not, such as transcriptions.

11. Young and Matheson, "The Metaphysics of Jazz," p. 129.

12. Young and Matheson, "The Metaphysics of Jazz," p. 131.

13. I defend a generalized version of the first suggestion below.

14. Richard Cochrane, "Playing by the Rules: A Pragmatic Characterization of Musical Performances," The Journal of Aesthetics and Art Criticism 58 (2000): 135-142, at pp. 140-141.

15. Young and Matheson, "The Metaphysics of Jazz," p. 131.

16. Cochrane does not consider so specific a suggestion, but he does say that "free improvisers often work to a vague score [that is, set of rules], which may be no more complicated than a verbal agreement. These, if acknowledged within the group to constitute a new performance practice that they may want to use again, could then constitute a new type" ("Playing by the Rules," p. 141).

17. Young and Matheson, "The Metaphysics of Jazz," pp. 132-133. Garry Hagberg can perhaps also be read as proposing a variable ontology for jazz. But this goes against the grain of his use of the term 'work-indeterminacy,' which suggests jazz works are all alike in their indeterminacy. (Garry Hagberg, "On Representing Jazz: An Art Form in Need of Understanding," Philosophy and Literature 26 [2002]: 188-198, at pp. 189-190.)

18. See, for example, Stephen Davies, "Ontologies of Musical Works," in his Themes in the Philosophy of Music (Oxford University Press, 2003), pp. 30-46.

19. S. Davies, “Ontologies of Musical Works," pp. 43-44.

20. Gould and Keaton, "The Essential Role of Improvisation," p. 144.

21. Young and Matheson, "The Metaphysics of Jazz," pp. $132-133$.

22. Andrew Kania, "Making Tracks: The Ontology of Rock Music," The Journal of Aesthetics and Art Criticism 64 (2006): 401-414.

23. Sometimes the centrality of improvisation to jazz is questioned on the basis of the slickness of performances captured on early recordings. Lee B. Brown cites some apparently more damning evidence: "alternative recording 'takes' of performances by Bessie Smith show that, as improvised as her phrasing sounds, it was probably often worked out in advance" (Lee B. Brown, "The Theory of Jazz Music: 'It Don't Mean a Thing. .."' The Journal of Aesthetics and Art Criticism 49 [1991]: 115-127, at p. 119). But a lack of improvisation in the early recording studio proves nothing about early jazz in general. By all accounts there was improvisation in jazz from its very beginnings. (It would be odd for a performer to practice an improvised sound if improvisation were not expected or valued by her audience.) At the same time, musicians are always concerned to be represented at their very best in recordings-the only enduring record of their performance skills (Simon Frith, Performing Rites: On the Value of Popular Music [Harvard University Press, 1996], pp. 232-233). But, of course, in the 1910s and 1920s, one could not record so many takes, let alone splice the best of various takes together into a reasonable representation of the musicians' skills. Thus, even if the performances captured on early recordings were in fact rehearsed, that is not a very strong argument against the centrality of improvised performance to the tradition those recordings are a part of.

24. Stephen Davies, Musical Works and Performances: A Philosophical Exploration (Oxford: Clarendon, 2001), p. 13.

25. Philip Alperson began the contemporary discussion of musical improvisation with "On Musical Improvisation." For useful reviews of the literature since then, see S. Davies, Musical Works and Performances, pp. 11-19, and Lee B. Brown, "Improvisation," in The Routledge Companion to Philosophy and Music, ed. Theodore Gracyk and Andrew Kania (New York: Routledge, 2011), pp. 59-69.

26. Such a construal is not trivial, and brings us to a point where I suspect intuitions vary or become vague. For instance, does a decision you make during your solo about how you will play the opening of the out-chorus make the way you play the beginning of the out-chorus improvised? I 
am not sure. However, if you decide to play a certain figure right now and then repeat it at the beginning of the out-chorus (all one decision), I would argue that this counts as one (extended) performance event, and thus both playings of the figure qualify as improvised on my account.

27. Janos Starker claimed that he does this in a questionand-answer session after a recital of Bach's first Suite for Solo Cello for the American Society for Aesthetics at their 1998 annual meeting (November 6, 1998, Indiana University, Bloomington, IN). Starker played with a facsimile of the manuscript in front of him, despite knowing the suites by heart. He said that graphic beauty of the penmanship inspires him to new interpretations during performances.

28. See, for example, Alperson, "On Musical Improvisation," and Gould and Keaton, "The Essential Role of Improvisation."

29. Young and Matheson, "The Metaphysics of Jazz," p. 127.

30. Young and Matheson, "The Metaphysics of Jazz," p. 127.

31. Young and Matheson, "The Metaphysics of Jazz," p. 127.

32. Young and Matheson, "The Metaphysics of Jazz," pp. 127-129. See also Alperson, "On Musical Improvisation," pp. 21-22; S. Davies, Musical Works and Performances, p. 12; and Lee B. Brown "Musical Works, Improvisation, and the Principle of Continuity," The Journal of Aesthetics and Art Criticism 54 (1996): 353-369, at p. 354 .

33. Clearly, anything more than a sketch of an account improvisation would require more to be said about the nature of these "decisions" and intentional action more generally.

34. For further consideration of these matters, see Brown, "Improvisation," pp. 66-68.

35. See S. Davies, Musical Works and Performances, pp. 16-17.

36. Such listening need not be ex nihilo any more than improvisation is. A listener can be well aware of not only other performances, but also any number of sound structures that various sets of those performances have in common (standard, chord progression, and so on), and these comparisons can be aesthetically relevant. But this does not make those performances performances of works; there is more to being a work of art than being a reinstantiable artistic structure, as we shall see below. For more on versions and transcriptions of (classical) musical works, see Stephen Davies, "Versions of Musical Works and Literary Translations," in Philosophers on Music: Experience, Meaning, and Work, ed. Kathleen Stock (Oxford University Press, 2007), pp. 79-92.

37. S. Davies, Musical Works and Performances, pp. 66-68.

38. André Hodeir, "Freedom and Its Limitations in Improvisation and Composition," reprinted in his Toward Jazz, trans. Noel Burch (New York: Da Capo, 1976), pp. 81-93, at p. 91.

39. For a parallel comparison between rock music and film, see Kania, "Making Tracks," pp. 408-409.

40. Hodeir, Jazz, pp. 90-93.

41. Alperson, "On Musical Improvisation," and Philip Alperson, "Improvisation: An Overview," in The Encyclopedia of Aesthetics, ed. Michael Kelly (Oxford University
Press, 1998), vol. 1, pp. 478-479; Hagberg, "On Representing Jazz"; S. Davies, Musical Works and Performances, pp. 16-19, and "Ontologies of Musical Works," p. 156.

42. Alperson, "On Musical Improvisation," p. 26.

43. Others who have defended something like this condition include Lee B. Brown (for example "Musical Works," pp. 353 and 366n2) and Paul Thom (For an Audience: A Philosophy of the Performing Arts [Temple University Press, 1993], p. 28). Alperson considers it briefly, but rejects it ("Improvisation: An Overview," pp. 478-479). For a fuller discussion of this issue in connection with improvised performances, see David Davies, Philosophy of the Performing Arts (Malden, MA: Blackwell, 2011), pp. 135-148.

44. For an extended consideration of this issue in connection with jazz, see Andy Hamilton, "The Art of Improvisation and the Aesthetics of Imperfection," The British Journal of Aesthetics 40 (2000): 168-185.

45. Robert Walser, “'Out of Notes': Signification, Interpretation, and the Problem of Miles Davis," in Jazz Among the Discourses, ed. Krin Gabbard (Duke University Press, 1995), pp. 165-188, at pp. 165-167.

46. Gracyk, Rhythm and Noise; John Andrew Fisher, "Rock 'n' Recording," in Musical Worlds: New Directions in the Philosophy of Music, ed. Philip Alperson (Pennsylvania State University Press, 1998), pp. 109-123; and Kania, "Making Tracks."

47. Brown, "Musical Works," p. 336.

48. Lee B. Brown, "Phonography, Repetition and Spontaneity," Philosophy and Literature 24 (2000): 111-125, at p. 121.

49. Gracyk, Rhythm and Noise, pp. 1-36.

50. Andrew Kania, "Works, Recordings, Performances: Classical, Rock, Jazz," in Recorded Music: Philosophical and Critical Reflections, ed. Mine Doğantan-Dack (Middlesex University Press, 2008), pp. 3-21, at p. 13. To the extent that jazz fusion is a fusion of jazz and rock techniques, it should be obvious why I hesitate to include fusion in my general theory. It is plausible that the ontological theory of rock that I have been considering here, or some variation on it, could be applied to fusion.

51. "Making Tracks," pp. 403-404. Indeed, due to the centrality of improvisation to jazz, even less studio manipulation is standardly allowed. For instance, individual note correction is much rarer.

52. Brown, "Musical Works." Note that Brown now rejects the view. See his "Do Higher-Order Musical Ontologies Rest on a Mistake?" The British Journal of Aesthetics 51 (2011): 169-184, especially pp. 175-179. I should note that although the latter article predates this one, Brown there responds to my arguments here. I have made some minor changes to this article in the meantime; I apologize to Brown and the reader for any resulting confusion.

53. Lee B. Brown, "'Feeling My Way': Jazz Improvisation and Its Vicissitudes-A Plea for Imperfection," The Journal of Aesthetics and Art Criticism 58 (2000): 112-123, at p. 115.

54. S. Davies, Musical Works and Performances, pp. 16-19; Stephen Davies, "Ontology of Art," in The Oxford Handbook of Aesthetics, ed. Jerrold Levinson (Oxford University Press, 2003), pp. 155-180, at p. 156.

55. Young and Matheson ("The Metaphysics of Jazz") and Hagberg ("On Representing Jazz") beg the question of whether there are works in jazz by simply beginning their 
inquiries with the question of what, rather than whether, works exist in jazz.

56. For helpful discussion of these issues, I thank Jerrold Levinson, an anonymous referee for the journal, and the audience at my presentation of an earlier version of this article at the 2006 Annual Meeting of the American Society for Aesthetics in Milwaukee. I am especially indebted to Lee Brown, not only for his comments on that occasion but also for teaching me so much about jazz and philosophy over the past thirteen years. Judging by his recent essay, "Do HigherOrder Musical Ontologies Rest on a Mistake?" I still have a lot to learn. 